\title{
Encountering Aboriginal knowledge: Explorer narratives on north-east Queensland, 1770 to 1820
}

\author{
Michael Davis
}

In early August 1802, botanist Robert Brown had a problem. He had secured a bounty of plants while exploring Port Curtis, today's Queensland town of Gladstone on the coastal fringe of Australia's tropical north-east, when he and his party were attacked by some local Aboriginal people. Brown wrote that 'The attack was made with a war woop \& discharge of stones: I was at this moment employ'd in putting specimens of Plants in paper \& had scarcely time to collect my scatter'd paper boxes \&c \& make a hasty retreat. ${ }^{1}$ Brown was accompanying Matthew Flinders on this survey of the region, having departed northwards from Port Jackson two weeks earlier. The plants had been collected and the task now was to package them securely, ready for the long journey back to the imperial centre. In this way, they became transformed from being parts of living ecosystems into botanical specimens for the enhancement of growing scientific and natural history collections. ${ }^{2}$

Brown's use of 'war woop' possibly references depictions of Native American sounds and gestures acquired from other contexts. He concluded of this encounter 'Thus ended our first skirmish with these poor unarm'd savages, in which they seemd to have much the advantage of us in point of bravery \& also in conduct'. ${ }^{3}$ In this primitivist discourse the savage is at once both 'ignoble' and 'noble'. ${ }^{4}$ There is a trope of lack, or negation in the reference to the 'poor unarm'd savages'; yet Brown's acknowledgement of the Aborigines' superior 'conduct' might imply his recognition of their greater knowledge of the country - a decided advantage in matters of battle. ${ }^{5}$

The attack with stones was not out of context. James Cook had sailed past this place at night in 1770 on the first of his three Pacific voyages, and it is not unlikely that the local Aboriginal people had seen the ships. News about sightings of strangers travelled through large areas of Aboriginal country and was conveyed

1 Brown's Diary, Thursday 5 August 1802, Vallance, Moore and Groves 2001: 238.

2 On the notion of transforming natural history into 'specimens', as 'artificial things, designed and constructed by naturalists to answer various scientific needs', see Larsen 1996: 358.

3 Brown's Diary, Thursday 5 August 1802, Vallance et al 2001: 238.

4 For representations of noble and ignoble savagery see Borsboom 1988. Bernard Smith's discussion of 'hard' and 'soft' primitivism is particularly apt here; Smith 1960. The literature on constructions of savagery is immense. For some seminal early studies see Smith 1960; Meek 1976.

5 On negation in colonial discourse see Spurr 1993. 
from group to group. Aboriginal people defended their lands, and were usually wary of intruders. It is not surprising then if those first moments of encounter, for the Aboriginal people at least, were shaped, among other factors, by fear, perhaps timidity, and possibly anger.

The Aboriginal people seen prior to the visitors' landing, Brown wrote, 'were on the beach but on our coming on shore left the beach \& retir' $\mathrm{d}$ to avoid an interview with us $^{\prime} .{ }^{6}$ The visitors' strategy to establish mutual understanding seems strangely comical. Brown wrote 'I proceeded straight into the country without taking any notice of them, judging that the best way of procuring an interview with them was by seeming not to pay attention to them'. This studied avoidance was reciprocated by the local people. But this exchange was no trivial matter, since much was at stake for all participants; for Brown it was at least the securing of botanical specimens, his primary objective on this voyage. For the local people it was perhaps nothing less than land and livelihoods. Brown wrote that the Aborigines 'did not seem to wish to have any intercourse with us, yet continued at a little distance to watch our motions \& on our attempting to ascend a rising ground we were saluted with a shower of stones, neither however well or forcibly thrown'. ${ }^{7}$ The stone throwing was a tactic intended as much as a warning as it was an act of violence in itself. Yet we know from readings of cross-cultural encounters elsewhere in Australia and the Pacific that hostility alone cannot always be read into parcels of behaviour; it is one of a vast array of responses. Native and stranger also engaged in tactics involving friendship, reciprocity and exchange in these theatres of encounter. ${ }^{8}$ There was often collaboration, and even companionship, alliances and friendship in these encounters. Aboriginal people participated in the European natural history project as guides, collaborators, and companions in many of these voyages. ${ }^{9}$

Apparently little fazed by the hostile action by the local Aboriginal people at Port Curtis, Robert Brown continued his botanising, noting some Pandanus and other plants 'not previously seen', and adding that 'the country was very generally burnt by the natives' ${ }^{10}$ Here is the I-witnessing - a common trope in voyaging narrative - of what was to the Europeans, novel flora. Aboriginal peoples' use of fire to 'manage' the landscape, and to secure game by flushing it out was not unknown by European observers; Cook and Banks remarked upon numerous smokes and fires seen during their 1770 voyage through this region. ${ }^{11}$ This fire-based land and environment management was just one visible sign of a coherent system of Aboriginal knowledge that was rarely if ever understood as such by these explorers. A coherent Aboriginal knowledge system, woven from all the myriad signs noted by the Europeans of the presence of the local people,

6 Brown's Diary, Thursday 5 August 1802, Vallance et al 2001: 237.

7 Brown's Diary, Thursday 5 August 1802, Vallance et al 2001: 237.

8 Vanessa Smith has written of friendship in European/Islander colonial encounters in the Pacific in Smith 2010; on the notion of 'theatricality' in history see Dening 1996.

9 On Aboriginal peoples' collaboration with botanists see for example Clarke 2011; on the role of Aboriginal people in European exploration more generally see Kennedy 2013.

10 Brown's Diary, Thursday 5 August 1802, Vallance et al 2001: 238.

11 See Gammage 2011. 
is suggested by observed traces and marks in and on the landscape including paths, remains of camping grounds, foods and food parts, fishing nets, barkshelters, and the range of material culture, and many other indications.

Brown's narrative presents many discursive practices. ${ }^{12}$ In the Port Curtis encounter the discourse of attack dominates. Yet tensions and anticipated hostilities are also juxtaposed with attempts towards mutual engagement, and there is a constant shifting to and fro between these. But what I am more interested in with these voyaging and exploration narratives is how the engagement between two radically different kinds of knowledge is textually represented. How can we read into the texts of these Aboriginal/European encounters, something about the complex entanglements between indigenous knowledge on the one hand, and what might be glossed as 'Western knowledge' on the other? There is a vast and growing body of global writings about indigenous knowledge. A good deal of this is concerned with current and emerging issues and debates in policy, legal protection regimes, and questions of definition, and the role of indigenous knowledge in development, anthropological and ethnobotanical studies. ${ }^{13}$ Questions involving protection of indigenous knowledge are often discussed in the context of this knowledge as a kind of 'intellectual property', a theme that invites considerable attention in itself. There is also a lively discussion in the literature around the characteristics of, and relationships between indigenous knowledge, science, and varieties of local and peoples' knowledge. ${ }^{14}$ Indigenous knowledge, historically, has been viewed as being of lesser validity than dominant Western knowledge, especially what is 'defined' as science. ${ }^{15}$ Colonial practices of exploration, 'discovery' and settlement have reinforced this view, rendering indigenous knowledge invisible in Europeans' eyes, or worse, subjugated within dominant knowledge regimes. While the unequal power relations in colonial situations mean that the subaltern voice ultimately cannot 'speak', is it possible to glean something of the role of indigenous knowledge in colonial exploration and voyaging encounters? ${ }^{16}$

12 I am using the concept of discourse here in the Foucaultian sense to mean 'dispersed and heterogeneous statements, the system that governs their division, the degree to which they depend upon one another, the way in which they interlock or exclude one another, the transformation that they undergo, and the play of their location, arrangement and replacement', Foucault 1974: 34. In this understanding discourse is not only language, speech and utterances, but the entire system in which these operate, are produced, and circulate, and includes all textual productions.

13 On legal/environmental aspects of indigenous knowledge, including in regard to intellectual property and biodiversity law see for example Anderson 2009; Curci 2010; Davis 1999, 2006, 2008; Gibson 2005; McManus 2002; Mgbeoji 2006; von Lewinski and Hahn 2004.

14 This is also a very large and growing body of literature. A few examples are Agrawal 1995; Anderson 2002; Brush and Stabinsky 1996; Dei, Hall and Rosenberg 2000; Ellen 2004; Green 2008; Sillitoe 2007; Turnbull 1997; Chambers and Gillespie 2000; Ellen, Parkes and Bicker 2000.

15 There is a very large literature on 'indigenous knowledge' and 'science'. See for example Agrawal 1995; Anderson 2002.

16 Spivak 1988. 
There is a large body of scholarship examining the working together of different knowledge traditions - European and non-Western. ${ }^{17}$ But what seems largely absent in much of this is an inquiry into the complex ways that Aboriginal and Western knowledge systems have intersected with, and shaped one another over time, within a particular locality. This article aims to address a gap in the literature on indigenous/European encounters in two ways. First, to understand how, and in what ways indigenous ecological knowledge and practices have informed, and contributed historically to the formation of scientific and other types of colonial knowledge. Second, and more specifically, to interrogate voyaging accounts for north-east Australia to consider how these might show that Europeans over time developed a growing awareness of the roles of Aboriginal environment-related knowledge.

To consider these themes, I select some events from explorer narratives by Brown and Flinders in 1802, and from a voyage in 1819 by Phillip Parker King, who was accompanied by botanist Allan Cunningham. In exploring entanglements between indigenous knowledge and various forms of colonising knowledge, including botany and geography, I envisage all these forms of knowledge not as homogenous entities, but as partial, highly localised, dispersed and situated. ${ }^{18}$ In focusing on these voyaging narratives, I am reading them not as unproblematic records of some absolute reality, but rather, as the products of a complex 'interplay of producers, subjects, contexts, discourses and audience'. ${ }^{19}$ Reading these texts 'against the grain' allows for tracing what Bronwen Douglas has termed indigenous 'counter-signs', the 'oblique stamp of indigenous actions, desires and agency on recorded imperial imaginings' ${ }^{20}$

Examining the narratives by botanists and naturalists on voyaging expeditions allows for an interrogation as to how, or indeed if, the activity of natural history observation, recording and collecting engaged with local Aboriginal peoples' environment-related knowledge and practices. On the face of it these activities - European botany and Aboriginal environmental knowledge - might appear to share some common ground. Here is Robert Brown intent on identifying plants in this new country, and making a fine collection to take back to Britain. Fascinated by this abundance of exotic nature, he names these species, employing the classification system developed by Carl Linnaeus in 1735. The Aboriginal people also have an interest in the natural world, though their relationships with nature are very different. They certainly classify the world around them - though in different ways, for different purposes. They emphasise plants and animals as part of a complete, living system, and the relationships between and among

17 For a selection of this literature see Davis 2006; Turnbull 1997, 2002, 2005, 2009; Verran 2002, 2009.

18 The literature on imperial science, and on science and 'other' knowledge traditions is very large. On the geography and 'spatial turn' in science see for example Powell 2007, for analyses of relationships between different types of knowledge including indigenous and scientific see Chambers and Gillespie 2000; Turnbull 1997; Agrawal 1995.

19 Douglas 1999: 68.

20 Douglas 1999: 68. For more on indigenous counter-signs see also Douglas 2009, 2010. 
species are as important as the individual plants or animals. ${ }^{21}$ In their cosmology, species are valued not only for their use, but also for their associations, for their symbolism, and for the part they play in the entire system. Informing these approaches to the nineteenth-century natural world by Europeans and Aborigines were two different knowledge systems. For many Europeans, nature was an object, a useful commodity, and a scientific specimen. ${ }^{22}$ Aboriginal people tend to see nature within a universe that connects humans, animals and plants with the ancestral domain. Although in broad terms these two systems - Western science and indigenous knowledge - may be constituted differently, there is not a binary opposition between them. In the entanglements between these different knowledge systems, there are points of commonality, as well as radical incommensurability. ${ }^{23}$

Local sites of encounter such as at Port Curtis are situated in global contexts. In the botanising work by Brown and his colleagues plants are transposed from their local ecosystems into specimens for imperial scientific botanical collections. This kind of transposition was symptomatic of the region in a wider sense, as a site for the juxtaposition of different colonising narratives and imaginaries. In a Eurocentric macro-narrative, this region of north-east Australia is a significant geo-political one for the developing colonial-settler project. In these wider narratives competing imperial power imperatives combine with multiple colonising projects of science, survey and appropriation. At the same time, these imperial projects inscribed and appropriated multiple local indigenous narratives through naming and classifying practices. Place-naming figures prominently in this colonising schema, and is a feature of these scientific voyaging narratives. For example, Port Curtis is named for Vice-Admiral Sir Roger Curtis, who had helped Flinders earlier while at the Cape of Good Hope. ${ }^{24}$ Naming places inscribes them in European colonial registers, and simultaneously erases or subjugates pre-existing indigenous referents. ${ }^{25}$

In these early years of the beginning of the nineteenth century, this region of north-east Australia began to be inscribed in the European imaginary through the detailed cartographic surveys and explorations of James Cook. Other European voyagers had earlier made brief landfalls or distant sightings of parts of this extensive eastern coast. The landmass that is today's Australia was known initially to Matthew Flinders as Terra Australis, and earlier Dutch

21 This has often been referred to as indigenous ecological knowledge. However, the use of 'ecology' here needs to be interrogated more closely, to distinguish it from ecology as a particular Western discipline. See Ellen 2006 for one useful contribution to an anthropology of different approaches to classifying.

22 This is not, however, to cast European science as a monolithic and static entity, or mode of understanding; rather, as with Western discourses more generally, they are seen as changing, dispersed and fragmented.

23 See for example Davis 2006 for a discussion. David Turnbull has discussed the idea of multiple knowledge traditions extensively; see for example Turnbull 1997, 2002, 2005.

24 Flinders 1814 [1966] vol II: 19.

25 Naming as a colonial discourse is extensively discussed by Paul Carter in his seminal work, Carter 1988. See also Spurr 1993. 
navigators and cartographers inscribed it as New Holland. ${ }^{26}$ Cook had already, on 22 August 1770, taken possession for King George III at a point on the Cape York Peninsula, naming this part of the north-east coast New South Wales. ${ }^{27}$ By the time Flinders was circumnavigating, the fledgling settlement at Port Jackson had been established and the imperial project was in full train, with much activity being given to the search for productive lands and resources, and for good rivers, harbours and ports. At the same time, in its pursuit of knowledge, the empire was busy collecting, cataloguing, classifying and recording, encoding the new and exotic into the familiar. Exotic fauna and flora were keenly sought for their value to science and for societal progress. In all this colonial knowledgemaking, Indigenous knowledge, mostly hidden, or rarely referenced in the explorers' narratives, played a vital part. In this grand scheme, the voyage of Flinders was part of a pattern of scientific botanical journeys of discovery, with Dampier's survey on the north-western Australian coast in 1688, the Cook and Banks expedition of 1770, and, some 50 years later, voyages such as that of Phillip Parker King, with botanist Allan Cunningham on this eastern coast in 1819.

On Flinders' voyage, Scottish born Robert Brown, one of the protégés of prominent and wealthy Enlightenment figure Joseph Banks, contributed to the project of collecting the natural world for British and global interests. His enthusiasm for botany had begun early, and he continued this keen interest while in Ireland in the Fifeshire Fencibles during the late 1790s. ${ }^{28}$ Following his botanical work in Australia, he returned to Britain where he spent years describing and publishing the collections he had made. In 1810 he became librarian to Joseph Banks until the latter's death in 1820, and he inherited Banks' library and herbarium. In 1837 he became Keeper of the Botanical Department of the Natural History Museum in London, and was President of the Linnaean Society from 1849 to 1853 . Brown's dedication to his botanical work undoubtedly contributed to the privileging in his journal of the pursuit of plants over discoursing on the hostile encounter with Aboriginal people. In the midst of the danger of violence at Port Curtis his chief concern was for continuity of access to the plants, and the safety of their packaging and transfer to the ship. But as we read further into Brown's narrative there is an emerging sense, albeit likely not an intentional one, of a richly textured landscape of Aboriginal environmental practices. Although on the face of it, the encounter is narrated in terms of avoidance, tension, and an aggressive act, the

26 The notion of 'Terra Australis', an unknown land of the south, stems from Aristotle and Ptolemy, and was transmitted through the cartographic representations and voyaging literature to Alexander Dalrymple, and thence to Matthew Flinders. He wrote: 'There is no probability, that any other detached body of land, of nearly equal extent, will ever be found in a more southern latitude; the name Terra Australis will, therefore, remain descriptive of the geographical importance of this country, and of its situation on the globe: it has antiquity to recommend it; and, having no reference to either of the two claiming nations, appears to be less objectionable than any other which could have been selected'.It is interesting to note that Flinders thought the term 'Australia' might be more appropriate; Flinders 1814 [1966] vol I: iii. The term 'New Holland' (Nova Hollandia) was coined by Abel Tasman, and was in force until Flinders changed it to Terra Australis and then Australia.

27 For Cook's journal at this point see Beaglehole 1955: 387-388.

28 Mabberley 1985: 31-34. 
detailed botanical discourse that runs through suggests a reading that this place, as elsewhere, is deeply imbued with an Aboriginal presence in, and engagement with the environment.

In the Port Curtis area the Bayali and other language groups have maintained their ancient knowledge of plants and other natural resources over thousands of years. This knowledge, which fashions their sense of place, is expressed in multiple ways, including through language and gesture, environmental management and food gathering activities, and in a variety of material forms. Their relationship to land and country, configured through the sacred geography of the ancestors, is constantly enacted and re-enacted through ceremony, song and dance, and in the everyday domain. Livelihood activities of food gathering, hunting, the preparation of food, dwellings, and all the work of material culture are vital elements in this place-making. Flinders offers his narrative of the Port Curtis encounter:

The naturalist and his companions landed at the west side of the entrance, where some Indians had assembled to look at the ship; but they retired on the approach of our gentlemen, and afterwards taking advantage of a hillock, began to throw stones at the party; nor would they desist until two or three muskets were fired over their heads, when they disappeared. There were seven bark canoes lying on the shore, and near them hung upon a tree some parts of a turtle; and scoop nets, such as those of Hervey's Bay, were also seen. ${ }^{29}$

Here, the stone-throwing incident seems quickly passed over, as Flinders' narrative shifts to observations on the visible signs of Aborigines' living patterns, food procurement and material culture. He noted that 'the country around Port Curtis is overspread with grass and produces eucalyptus and other trees common to this coast; yet the soil is either sandy or covered with loose stones, and generally incapable of cultivation' ${ }^{30}$ His story largely replicates that of Brown, except for his use of the term 'Indians', reflecting a discourse of primitivism transposed from the Americas (akin to Brown's use of 'war woop'), and his account of the number of canoes seen. But again, there are multiple layers of discursive practice operating here. Jostling with a primitivist discourse, there is also a comparative ethnology ('scoop nets like those at Hervey Bay'), and the often-present discourse of conflict, interspersed with attempts at communication. There is also a consistent discourse on productivity of land and resources - another prominent feature of these voyaging narratives, consistent with the prevailing Enlightenment ideas about 'improvement'. The text is at once, manners and customs reportage, as well as cartographic and geographic survey.

As well as these multiple, intersecting discourses within a single text, there seems to be a disconnection between the discourses about interactions between the

29 Flinders 1814 [1966] vol II: 15-16.

30 Flinders 1814 [1966] vol II: 19, italics in original. 
Aborigines and the intruders, and those having to do with botanical and other ecologically based matters. The botanists continue naming and collecting plants, in the midst of all the activity that the encounter entails. Scenarios of conflict are juxtaposed with details of plants and animals identified and collected, and comments on Aboriginal fishing, plant use, burning and other environment based practices, as well as comments on the Aborigines themselves. Although apparently fluently presented in the flow of the narrative, these discourses, all present within a single text, are also at odds with one another in their content and style.

Another perspective on the Port Curtis encounter comes from the pen of ship's gardener Peter Good, who accompanied Brown in the botanical work. On 5 August, Good recorded 'several large Canoes on the Beach \& some Natives to the North of entrance'. Here, he wrote, 'Mr Brown \& Party went ashore'. At this point:

a number of Natives appeared making Gestures as we approached the Shore but on coming near they all run into the woods - We walked on in search of Natural History without paying any attention to them \& crossed a neck of land till we found ourselves on an Arm of this large Bay - many Natives before us but would not permit us to come near them always retreating as we advanced on advancing to a little hill covered with Trees they threw a number of Stones towards us \& kept among the Bushes out of sight - on our advancing up the hill they disappeared -we continued to advance till we came to the opposite side of the hill \& in going down the bank the Natives gave the War Song \& rushed out among the Bushes in different directions, throwing stones \& sticks at us they appeared to have no Spears we got into an open space at the bottom of the hill and fired some Muskets in the Air when they all run [sic] away as fast as they could run - on returning to the Shore we found the Shell of a very large Turtle which they had been roasting very lately, the head \& part of the flesh was still firm - a great part of the flesh of Turtle hung up in a Tree of the Pandanus odoratissima so that it appears they live in luxury - they had many fishing nets \& cordage about the Beach executed in the same manner as at Sandy Cape - Their Canoes were similar to those at Port Jackson but much larger \& better executed... ${ }^{31}$

Here, as in Brown's text, the naming of this particular type of Pandanus palm tree in the Linnaean system implies that these species were already known from elsewhere. This is another feature of these narratives, indicating their position in a wider discourse of botanical voyaging expeditions. The taxonomic classificatory discourses of Flinders', Brown's, and Good's narratives inscribe a dominant European knowledge onto pre-existing Aboriginal systems.

Peter Good's story again weaves together multiple discourses. He has different ways with language in his description of the scene. Here, the Aborigines 'making

31 Edwards 1981: 83-84. 
gestures' might be construed as giving warning. Brown had not referred to this gestural event, but it conveys a wider range of meanings than does the hostile act of throwing stones. Good's phrase 'in search of Natural History' similarly opens up more possibilities for conjecture about the botanical collecting project. Searching for natural history might embrace more than just cataloguing, classifying and collecting. Flinders' scientific enterprise was as much visually oriented, as it was object focused. The ship's contingent included British landscape painter William Westall and Austrian botanical illustrator Ferdinand Bauer. The Europeans' engagement with nature was as much a project of seeing, as it was of documenting and collecting, as the artists contributed to the visual representation of place and peoples. As well as the eye of the explorer, the play of sounds is also evident in the representation of the Aborigines' utterance accompanying their stone-throwing. In Good's account, Robert Brown's 'war woop' becomes a 'War Song', perhaps somewhat less culturally laden, and suggestively inviting inquiry into the representation of sound in these colonial encounters. The gardener's comment that 'it appears they live in luxury' speaks to a discourse on the relative patterns of Aboriginal resource procurement, and the ecologies and economics of livelihoods. Good's narrative also shows the discourse of comparative ethnology, and markers of cultural difference as he references an absence of spears, observations of fishing nets and cordage, similar to what had been seen at Sandy Cape, and canoes that differed from those noted at Port Jackson. As in all these texts, Good's narrative interweaves descriptive accounts of Aboriginal environmental and food gathering and preparation activities together with the dramas of the conflict. In all this jostling of discourses there are also hints of a coherent ecological system at work in all the signs of Aboriginal living (his 'live in luxury' comment).

\section{Botanising and engagement with Aborigines at Sandy Cape, Hervey Bay: Brown and Flinders, late July 1802}

Not all encounters involved conflict or violence. Only a few days earlier further south, relations with the Aboriginal people had seemed less fractious, despite a tense initial meeting. Here, at the end of July, Flinders and party had reached Sandy Cape near Hervey Bay. They anticipated some good botanising as Flinders wrote in his journal 'in order to give the botanists an opportunity of examining the productions of Sandy Cape, I determined to remain here a day' ${ }^{32}$ Some Aboriginal people were observed on the beach, and a boat was dispatched 'to commence an acquaintance with them'. Flinders noted that they 'retired, and suffered Mr. Brown to botanise without disturbance'.$^{33}$ Although no conflict ensued in this encounter, there is here, as at Port Curtis, a disconnection between the discourses on relations with Aborigines, and those on the botanising project. From this extract it might be supposed that the presence of the local people was seen as a hindrance to the botanising. There is once again the avoidance - though

32 Flinders 1814 [1966] vol II: 10. See also Vallance et al 2001.

33 Entry for Friday 30 July 1802 in Flinders 1814 [1966]: 10. 
on this occasion we are not told of any subsequent aggression. The disjuncture in the text between the pursuit of the botanical project and the apparent reticence, fear or disinterest of the Aboriginal people precludes the possibility for mutual engagement or exchange in ecologically based matters. The botanists' objectives were to identify, document and collect plants, and to ensure their safe packaging ready for the imperial museums and scientific study. At the same time, the local groups - here the Butchulla clans of Fraser Island, Gubbi Gubbi and others were engaged in their own, ancient systems of maintaining, transmitting and performing their ecological knowledge based practices.

We cannot know if in their attempts to make the 'acquaintance' of the local Aborigines, Flinders' party had in mind to specifically inquire into, or draw upon these peoples' knowledge of the country and its ecology. If this entry from Brown's narrative is taken as an example for the depiction of these kinds of encounters, we would not have much to say about a history of how Aboriginal knowledge and Western science engage. By 'engage', here I mean meetings in which there is some degree of shared understanding and meaningful communication. Instead, it appears from this that the Europeans, in Greg Dening's words, 'played out their own cultural systems in caricatured charades'. ${ }^{34}$ From this brief scenario we would be wondering whether the Investigator's botanists had any interest in listening to the Aborigines' talk about plants, in being attentive, in David Abrams' sense, to 'the sounds of an oral language - to the rhythms, tones, and inflections', ${ }^{35}$ let alone actively seeking the Aborigines' knowledge to assist in the identification and procurement of the local flora. ${ }^{36}$ Instead, our historymaking might conclude that the presence of local people was regarded, at best as irrelevant, and at worst, as disruptive of the Europeans' precious botanical work. Yet we know from the wider record of these voyaging explorer narratives that Europeans and Aborigines often acted together in the botanical work - although the respective meanings each attached to this project may have differed. As historian Philip Clarke says 'British colonists who came in 1788 to establish themselves in the "new" country found the indigenous land "owners" to be both a physical threat and an important source of information about the environment' ${ }^{37}$ These ambivalences may be equally true for the explorers and surveyors during later years. Many explorers were accompanied by Aboriginal people who acted as guides and interpreters, and who might also have assisted in the botanical work, including in collecting plants. But it is not clear in the narratives by Flinders and Brown, as it is in some later botanists' and voyagers' accounts such as those of King, Cunningham and subsequent expeditions, that

34 Dening 1980: 19.

35 Abram 1996: 140. See also Troy 1996 and Carter 1996 for discussions relating to European and Aboriginal encounters and the role of sound, dialogue and language.

36 We do know from historical records of encounters in other parts of Australia, that Europeans and Aboriginal people worked together in a common enterprise of botanical collecting and identification of species, with Aboriginal people as guides and collectors; see Clarke 2008: 6.

37 Clarke 2008: 6. 
the botanists worked closely with local Aboriginal people at a particular place, in ways that enabled the Europeans to acquire a greater understanding of the role of Aboriginal environment-related knowledge.

In considering further the narrative of this encounter at Sandy Cape, the scene becomes more complex. The men had separated to pursue their various activities, with the 'naturalist's party' walking along the shore towards the upper part of the bay, while Flinders and six others, including the Aboriginal man Flinders referred to as his 'native friend Bongaree', proceeded to the extremity of the Cape. ${ }^{38}$ Here, there were 'several Indians with branches of trees in their hands'. Flinders describes the ensuing actions:

whilst they retreated themselves, [they] were waving for us to go back. Bongaree stripped off his clothes and laid aside his spear, as inducements for them to wait for him; but finding they did not understand his language, the poor fellow, in the simplicity of his heart, addressed them in broken English, hoping to succeed better. ${ }^{39}$

Here language and material exchanges play key roles in this scene, but the meetings are enacted in a theatre of ambiguity, misread signs, and unequal power relations. Flinders reports that 'at length they suffered him to come up, and by degrees our whole party joined; and after receiving some presents, twenty of them returned with us to the boats, and were feasted upon the blubber of two porpoises, which had been brought on shore purposely for them'. These exchanges concluded when 'the naturalists returned, bringing some of the scoop nets used by the natives in catching fish; and we then quitted our new friends, after presenting them with hatchets and other testimonials of our satisfaction' ${ }^{40}$ The assumption here that Bongaree would share language with Sandy Cape people, is at odds with an indication, suggested elsewhere in these texts, of the localised nature of language and cultural groups.

The intertwined discourses on Aboriginal presence, and on observations on the country around Sandy Cape and its resources can be seen again, in the following entry from botanist Robert Brown's diary:

we saw no natives but in many places found the shrubs \&c on fire, \& in one part of the beach a range of fences from the wind \& one hut formd, as in the neighbourhood of Port Jackson, of a piece of Bark bent in the middle.

... Not far from the beach we found about a dozen fishing nets of the Natives, part of which we carried off leaving a hatchet \& red night cap in their stead, but seeing some of the natives approaching towards us

38 Flinders 1814 [1966] vol II: 10, italics in original.

39 Flinders 1814 [1966] vol II: 10. There are variations in the spelling of Bungaree/Bongaree. While Flinders uses Bongaree, this man's name is rendered Bungaree by McCarthy 1966; Douglas 2007; and Smith 1992. Smith notes many of the variations of spelling in his Appendix I, 1992: 168-169.

40 Flinders 1814 [1966] vol II: 10. 
we took up the hatchet \&c. On their join[in]g us, which they did only three in number \& without arms, they demanded their nets, which we returned to them but again bargained for some of them, giving them 2 hatchets and 2 red night caps in return which they seemd to take as an equivalent.

On our join[i]ng the Capns party we found many of the natives along with them \& learned that they had had intercourse with them soon after we left them. This intercourse was brought about by Bongare [Bongaree] the Port Jackson native who, unarmd, boldly went up to a considerable party of them armd with spears $-{ }^{41}$

This was a scene of multiple exchanges, in a setting of confused or misconstrued notions about the relationships between material objects, gift and exchange, and the roles of these for communication and shared understanding. Bongaree, as Flinders' friend and guide, here asserted an important role in assisting the Europeans to establish communication with the local Aboriginal people, but it ultimately once again proved unsuccessful, as Flinders notes, 'our native did not seem to understand a word of their language, nor did they seem to know the use of his womerah or throwing stick'. Here, Flinders' articulates a discourse on comparative ethnology in his observations of different Aboriginal traditions and material culture in different locations:

one of them being invited to imitate Bongaree, who lanced a spear with it very dexterously and to a great distance, he, in the most awkward manner, threw both womerah and spear together. Nothing like a canoe was seen amongst these people; but they must have some means of passing over the water to short distances, since I found, in 1799, that Curlew Islet, near the head of this bay, had been visited. ${ }^{42}$

Bongaree's presence during Flinders' expedition was crucial. Bronwen Douglas has pointed to Bongaree/Bungaree's role as a mediator and intermediary, arguing that 'the content and wording of [Flinders'] own journal suggest that the most potent element in local responses to the strangers [the Europeans] and repeated expression of eagerness to communicate with them was Bungaree' ${ }^{43}$

The apparent absence of canoes and of knowledge of the woomerah in this text can be read as markers of lack in a hierarchy of primitivism. There is the assumption of savagery as the intruders 'took up the hatchet' the moment they saw the Aboriginal people approach. Jostling with this discourse of cultural difference and of savage otherness, is one on the relative productivity of nature, and a general assessment of the suitability of this place for a harbour. The absence of elements of material culture here suggests the kind of 'hard primitivism' sometimes attributed to the Australian Aborigines, wherein the people were 'modern exemplars of the austere virtuous lives led in classical

41 Brown's Diary, Saturday 31 July 1802, Vallance et al 2001: 231.

42 Flinders 1814 [1966] vol II: 11.

43 Douglas 2007: 19. 
time by such peoples as the Spartans and the Scythians' ${ }^{44}$ But this absence can also be interpreted as a marker of 'soft primitivism', the noble savage, man in a state of nature, an Enlightenment image that was re-affirmed by Europeans' encounters with Polynesians in the eighteenth century. ${ }^{45}$ Representations of these local people here then are caught between the noble and the ignoble savage. The observations of Aborigines by Cook and Banks, which led them to generally typify Aborigines as noble savages, were by now, some three decades later, tempered by Europeans' greater experience with indigenous peoples, and changing European attitudes. The settlement at Port Jackson, and subsequent encounters had destabilised the Rousseauian romanticism of the noble savage. Although it was not quite the case that the 'pendulum had swung firmly to the side of civilization', there was an increasing tension between the savage as noble and ignoble. ${ }^{46}$ The ignoble savage was now in greater tension with ideas of noble savagery, and the interplay between these representations was common in Enlightenment and later travel narratives. ${ }^{47}$ The stadial construct of primitivism that saw hunter-gatherers low in a hierarchy that was based on relative subsistence modes, did not convincingly hold up when Europeans came to see the livelihoods of Aboriginal people more closely. Here the native was neither noble nor ignoble, but rather something more complex: a kind of 'protoeconomic' man. Here was the primitive economy in all its richly evident detail, as the explorers noted abundant evidence of a distinctly Aboriginal mode of production that appeared finely tuned to the availability of food resources and environmental conditions.

In Robert Brown's journal for Sandy Cape there is the dominant discourse, as to be expected, of botany. But he too displays a comparative ethnological discourse, with tropes of primitivism, with comments on difference and similarity in noting various aspects of Aboriginal people's physical characteristics, including skin colour, physical markings and bodily adornment ('in their features, colour $\& c$, they are precisely similar to those of P[ort] Jackson', 'In size they appeard somewhat inferior' $).{ }^{48}$ But Brown's botanical discourse is of particular interest in my inquiry into the shaping of discourses of indigenous knowledge and Western science. He writes:

It is rather surprising however that at none of their fires, of which we saw many, did we meet with any fish bones or fragments of shell fish, But at all of them the flowering amenta of Banksia verticillata \& the scarce ripe fruit of Pandanus odoratus /?/ in considerable quantity. As we found many nearly ripe Legumens of the species of Dolichos, which is so common on the shores unattached to the growing plants, I suppose

44 Smith 1960: 22.

45 See Smith 1960.

46 Coleman 2005: 424. See also Strong 1986.

47 Borsboom 1988; Strong 1986.

48 Brown's Diary, Saturday 31 July 1802, Vallance et al 2001: 231. 
either from prejudice or experience of its hurtful effects they forbear eating this bean, which as far as I could judge from its taste I should suppose a safe \& nutritious food..$^{49}$

This text maintains the theme of inscribing a Linnaean taxonomy onto Aboriginal peoples' lands and environments, but it also does something more. Brown's puzzlement about likely Aboriginal eating preferences hints at an awareness of an underlying sense of the local peoples' toxicological knowledge concerning food plants. Combined with his keenly observed remarks on what was seen, and what seemed curiously absent from the vicinity of Aboriginal campfires, this extract from Brown's journal allows for a more layered reading of intersecting discourses on European and Aboriginal philosophies of nature and ecological knowledge. Here again is the exemplar Homo economicus, underpinned by a system of living in the natural world that was welded together by an unseen knowledge.

These occasional glimpses of a system of food and ecologically based knowledge can also sometimes be seen in Flinders' journal. Arriving at Keppel Bay, further north of Hervey Bay on 9 August, the explorer's eye for the lie of the land is well presented as he writes 'my object in stopping at this bay was to explore two openings marked in it by captain Cook, which it was possible might be the entrances of rivers leading into the interior' ${ }^{50}$ Flinders' text displays the play of different discourses as he deftly shifts from remarks on physical appearance, to comments on visual indications of the Aborigines' eating and living arrangements:

It is scarcely necessary to say, that these people are almost black, and go entirely naked, since none of any other colour, or regularly wearing clothes, have been seen in any part of Terra Australis. About their fire places were usually scattered the shells of large crabs, the bones of turtle, and the remains of a parsnip-like root, apparently of fern; and once the bones of a porpoise were found; besides these, they doubtless procure fish, and wild ducks were seen in their possession. ${ }^{51}$

Here is the now familiar repertoire of competing imagery, with depictions of skin colour and nakedness, typical tropes of primitivism. ${ }^{22}$ Yet these representations of native otherness are interleaved with a discourse of biology and the abundance of nature, as Flinders notes the presence of kangaroos, bustards, and a variety of other species including curlews, gulls, 'and some lesser birds', as well as oysters. And again, there is an oddly discordant relationship between these discourses. The abundance of species, combined with Flinders' observations on the food

49 Brown's Diary, Saturday 31 July 1802, Vallance et al 2001: 231.

50 Flinders 1814 [1966] vol II: 22.

51 Flinders 1814 [1966] vol II: 30.

52 See Konishi 2012 for an excellent discussion of representation of skin and bodies of Aboriginal males in eighteenth century explorers' texts. 
resources scattered around the camp fire site might be read as suggesting an underlying Aboriginal domain in which food preferences, modes of procurement and other ecologically based livelihood features are prominent.

The diversity of discourses of botany, race and difference, and of productivity of nature, jostling within the performances of tense colonial encounters, is again apparent in the narrative of Allan Cunningham, botanist on the survey voyage by Phillip Parker King nearly two decades after Flinders and Brown were exploring and collecting in this part of coastal Queensland.

\section{The pursuit of flora ruptured by the natives: Allan Cunningham at Endeavour River, 1819}

In November 1819, reflecting on the events in June of that year at the Endeavour River, near present day Cooktown, Cunningham complained to his mentor Joseph Banks:

Here was a period of 14 Days, that might have been wholly at my Disposal, had it not been for the annoyances experienced from the 'Prowling' natives, who made a rather determin'd but unsuccessful attack upon the Boat builders and others on shore, while I was at some Distance in pursuit of Flora, which fully occupied my time ... it was a subject of much Regret to me, that in consequence of the Rupture with the Natives, my Walks during the last Week of our stay at Endeavr. River, were either very much circumscribed, or wholly prevented..$^{53}$

It seems that Cunningham did not consider that his botanical work might have been enhanced or enriched by the local knowledge held by the area's inhabitants. He continued:

I had determined (in an absence of two days, at least, from the vessel) upon an excursion to the more distant and loftier hills, where woods densely matted to their summits would doubtless have afforded considerable scope for research. This however was wholly frustrated by the decidedly hostile dispositions of these Australians. ... I trust, however, that the specimens gathered at Endeavour River will prove an acceptable renovation of the plants preserved at Soho Square and originally discovered by yourself and Dr. Solander in July and August, $1770 .^{54}$

Cunningham's complaint that the local Aboriginal people were jeopardising his collecting activities echoes the narratives of Flinders and Brown, in which we saw the botanical work being hampered, or at least studiously ignored by the Aborigines. This seems to be a persistent theme. Avoidance behaviour by

53 Allan Cunningham to Joseph Banks, 8 November 1819, cited in Clarke 2008: 77; see also Lee 1925: 429-434.

54 Lee 1925: 430. 
the Aborigines, motivated by many factors, not least of which was likely fear, appears frequently in many of these encounter narratives. But this was by no means their only response to the visitors. Although this article is concerned with voyaging texts on north-east Australia, the historical record shows many examples of Aboriginal people and botanists working together during exploration expeditions in various parts of Australia. ${ }^{55}$

Surrey born Cunningham was, like Robert Brown, a 'Banksian collector'. ${ }^{56}$ By the time of his visit to this part of Australia he had participated in John Oxley's 1817 inland journey through the Blue Mountains to seek the sources of the Lachlan and Macquarie Rivers, and was now an experienced explorer and botanical collector. He had some interest in, and knowledge of Aboriginal people. He had visited Tasmania earlier in 1819, where he had 'spent some time trying to compile a vocabulary of their language' ${ }^{57}$ Compiling lists of Aboriginal words was a common enough activity from the earliest explorations, including during the voyage of Cook and Banks in 1770. Words and language are of course significant vehicles for, or indicators of indigenous knowledge. Although at Endeavour River, hostile relations were jeopardising Cunningham's botanising, there was communication, and the botanist was attentive to the local language. He wrote:

It appears rather singular that of a dozen natives, with whom we communicated a day or two previous to the commencement of open hostilities, and who were very communicative, they had no idea of the word kangaroo, although they knew the animal we spoke of, as well by our signs as by its frequency on the rocky hills around us. The animal bearing the generally established name of kangaroo throughout Europe they called Mauya (or Menuah). ${ }^{58}$

This linguistic confusion was in part brought about by the term kangaroo having been taken by Europeans from Cook and Banks' visit to the Endeavour River in 1770, circulated through England, and brought back with King, who had assumed a universality of the word among all Aboriginal people. ${ }^{59}$

Like Cunningham, some Europeans were curious about the Aboriginal peoples' words for things seen, for animals and plants. Yet at the same time, and oddly lacking congruency with this, their interest in Aboriginal peoples' knowledge of the natural world, their language, and their material culture was predominantly

55 Cunningham worked closely with individual Aboriginal people during several of his botanical expeditions elsewhere in Australia. While at King George Sound for example in 1821 he was accompanied and assisted in his botanising by a local Aboriginal man referred to as 'Jack'; see Clarke 2008: 74 citing King 1827. Another of the many examples is the collaborative friendship formed between another Banks sponsored collector, George Caley, and a young Eora man named Moowat'tin during Caley's expeditions in the early 1800s. On this, see Turnbull 2000.

56 See Mackay 1996 for Joseph Banks and his circle of botanical collectors.

57 McMinn 1970: 41.

58 Allan Cunningham in Lee 1925: 430-431.

59 For the Guugu Yimidir language and the naming of the Kangaroo by Banks and Cook, see Haviland 1974; also see Cilento 1971; Sharman 1974. 
museological in its orientation. Words, language, and cultural objects of Aboriginal people were regarded in similar ways to the plants and animals being identified and collected: that is, as things to be classified and ordered according to predetermined registers and ideas, separate from their living contexts.

\section{Encounters and the role of Aboriginal knowledge}

Tensions, misunderstandings, and conflict are frequent in these encounters, and the explorer narratives give much play to these. Yet amidst the conflict we also find exchanges, trade, and communication of sorts, no matter that it is typically strangely placed, often misconstrued, and bears different meanings and intentions to the different actors. There are parallel discourses too, that have more to do with the steady and detailed work of botanical and geographicalsurvey exploration, with the Europeans also keenly noting ethnological details and Aboriginal food gathering, preparation and environment-related activities. In this sense, if any generalisation can be offered about the kinds of textual representations about Indigenous knowledge in these narratives, it is of a distinct Aboriginal cultural and economic livelihood system - one that is neither typically one of noble nor ignoble savagery.

In this article I have begun to interrogate the relationships between two different types of knowledge in early colonial encounters in this part of Australia, as represented in explorer texts. These encounters can, I suggest, be understood by focusing on the specifics of places, or sites in which they occur, and on the reported particularities - the language, actions, gestures, movements - of meetings between voyagers and Aborigines. It is at these sites of encounter, and in their textual forms, that different kinds of knowledge jostle and 'interrogate' one another to form a complex discourse. ${ }^{60}$ Close scrutiny of these explorer texts conveys a sense that there is another knowledge system at work, barely visible, yet critical in forming a particular type of colonial knowledge - one shaped from the entanglements between European and Aboriginal knowledge. The sites of encounter between Aboriginal people and Europeans, with their multiple discourses and representative practices might be read for the ways in which plural, intersecting knowledge systems and ideas about ecology engaged. This engagement results in the production of new forms of colonial knowledge, and is also critical in the shaping of imperial natural history science.

60 Historian David Turnbull has argued that 'the future for local knowledge traditions is ... dependent on the creation of a third space, an interstitial space in which the local knowledge traditions can be reframed, decentred and the social organisation of trust can be negotiated', Turnbull 1997: 560. 


\section{References}

Abram, David 1996, The Spell of the Sensuous, Vintage Books, New York.

Agrawal, Arun 1995, 'Dismantling the divide between indigenous and scientific knowledge', Development and Change 26: 413-439.

Anderson, Jane 2009, Law, Knowledge, Culture: The Production of Indigenous Knowledge in Intellectual Property Law, Edward Elgar Publishing, Cheltenham.

Anderson, Warwick 2002, 'Introduction - postcolonial technoscience', Social Studies of Science 32(5/6): 643-658.

Beaglehole, James Cawte (ed) 1955, The Journals of Captain James Cook on His Voyages of Discovery: Vol I The Voyage of the Endeavour 1768-1771, Cambridge University Press, Cambridge.

Borsboom, Ad 1988, 'The savage in European social thought: a prelude to the conceptualization of the divergent peoples and cultures of Australia and Oceania', Bijdragen tot de Taal-, Land-en Volkenkunde 144(4): 419-432.

Brush, Stephen B and Doreen Stabinsky (eds) 1996, Valuing Local Knowledge: Indigenous People and Intellectual Property Rights, Island Press, Washington DC.

Carter, Paul 1988, The Road to Botany Bay: An Exploration of Landscape and History, Alfred A Knopf, New York.

- 1996, 'Repetitions at night: mimicry, noise and context', in Ross Gibson (ed), Exchanges: Cross-cultural Encounters in Australia and the Pacific, Museum of Sydney and Historic Houses Trust of NSW, Sydney: 22-57.

Chambers, David Wade and Richard Gillespie 2000, 'Colonial science, technoscience, and indigenous knowledge', Osiris 15 (2nd series): 221-240.

Cilento, Sir Raphael 1971, 'Sir Joseph Banks, F. R. S., and the naming of the Kangaroo', Notes and Records of the Royal Society of London 26(2): 157-161.

Coleman, Deidre 2005, Romantic Colonization and British Anti-Slavery, Cambridge University Press, Cambridge.

Clarke, Philip A 2008, Aboriginal Plant Collectors, Rosenberg Publishing, Kenthurst, New South Wales.

- 2011 Aboriginal People and their Plants, 2nd ed, Rosenberg Publishing, Kenthurst, New South Wales.

Curci, Jonathan 2010, The Protection of Biodiversity and Traditional Knowledge in International Law of Intellectual Property, Cambridge University Press, Cambridge. 
Davis, Michael 1999, 'Indigenous rights in traditional knowledge and biological diversity', Australian Indigenous Law Reporter 4(4):1-32.

Davis, Michael 2006, 'Bridging the gap or crossing a bridge? Indigenous knowledge and the language of law and policy', in Bridging Scales and Knowledge Systems: Concepts and Applications in Ecosystem Assessment, Walter V Reid, Fikret Berkes, Thomas J Wilbanks, and Doris Capistrano (eds), Island Press, Washington DC: 145-163.

Davis, Michael 2008, 'Indigenous knowledge: beyond protection, towards dialogue', Australian Journal of Indigenous Education 37, Supplement: 25-33.

Dei, George Sefa, BL Hall and D Goldin Rosenberg (eds) 2000, Indigenous Knowledge in Global Contexts: Multiple Readings of Our World, University of Toronto Press, Toronto.

Dening, Greg 1980, Islands and Beaches: Discourse on a Silent Land: Marquesas 1774-1880, Melbourne University Press, Melbourne.

- 1996, Performances, Melbourne University Press, Melbourne.

Douglas, Bronwen 1999, 'Art as ethno-historical text: science, representation and Indigenous presence in eighteenth century and nineteenth century oceanic literature', in Double Vision: Art Histories and Colonial Histories in the Pacific, Nicholas Thomas and Diane Losche (eds), Cambridge University Press, Cambridge: 65-99.

- 2007, 'The lure of texts and the discipline of praxis: cross-cultural history in a post-empirical world', Humanities Research XIV(1): 11-30.

- 2009, 'In the event: Indigenous countersigns and the ethnohistory of voyaging', in Oceanic Encounters: Exchange, Desire, Violence, Margaret Jolly, Serge Tcherkezoff, and Daniel Tryon (eds), ANU E Press, Canberra: 175-198.

- 2010, 'Seaborne ethnography and the natural history of Man', The Journal of Pacific History 38(1): 3-27.

Edwards, Phyllis I (ed) 1981, The Journal of Peter Good: Gardener on Matthew Flinders Voyage to Terra Australis 1801-03, Bulletin of the British Museum (Natural History), Historical Series Volume 9, London.

Ellen, Roy 2004, 'From ethno-science to science, or "what the Indigenous Knowledge debate tells us about how scientists define their project"', Journal of Cognition and Culture 4(3): 410-450.

- 2006, The Categorical Impulse: Essays in the Anthropology of Classifying Behaviour, Berghahn Books, New York and Oxford. 
Ellen, Roy, P Parkes and A Bicker (eds) c2000, Indigenous Environmental Knowledge and its Transformations: Critical Anthropological Approaches, Harwood Academic, Amsterdam.

Flinders, Matthew 1814 [1966], A Voyage to Terra Australis, G. And W. Nicol, London, [Australiana Facsimile Editions No. 17, Libraries Board of South Australia, Adelaide].

Foucault, Michel 1974, The Archaeology of Knowledge, Tavistock Publications, London.

Gammage, Bill 2011, The Biggest Estate on Earth: How Aborigines Made Australia, Allen \& Unwin, Crows Nest, New South Wales.

Gibson, Johanna 2005, Community Resources: Intellectual Property, International Trade and Protection of Traditional Knowledge, Ashgate Publishing, Aldershot, Hants, England.

Green, Lesley JF 2008, “"Indigenous knowledge" and "science": reframing the debate on knowledge diversity', Archaeologies: Journal of the World Archaeological Congress 4(1): 144-163.

Haviland, John B 1974, 'A last look at Cook's Guugu Yimidhirr word list', Oceania 44(3): 216-232.

Kennedy, Dale 2013, The Last Blank Spaces: Exploring Africa and Australia, Harvard University Press, Cambridge, Massachusetts.

King, Phillip Parker 1827, Narrative of a Survey of the Intertropical and Western Coasts of Australia. Performed between the years 1818 and 1822 with an Appendix containing various subjects relating to hydrography and natural history, Vol II, John Murray, London.

Konishi, Shino 2012, The Aboriginal Male in the Enlightenment World, Pickering \& Chatto, London.

Larsen, Anne 1996, 'Equipment for the field', in Cultures of Natural History, N Jardine, JA Secord and C Spary (eds), Cambridge University Press, Cambridge: 358-377.

Lee, Ida 1925, Early Explorers in Australia: From the Log-Books and Journals, Including the Diary of Allan Cunningham, Botanist, from March 1, 1817, to November 19, 1818, Methuen \& Co, Ltd, London.

Mabberley, David J 1985, Jupiter Botanicus: Robert Brown of the British Museum, British Museum (Natural History), London and Verlag Von J Cramer, Braunschweig. 
McCarthy, Frederick D 1966, 'Bungaree (?-1830)', Australian Dictionary of Biography, Vol I, Melbourne University Press, Melbourne: 77.

Mackay, David 1996, 'Agents of empire: the Banksian collectors and evaluation of new lands', in Visions of Empire: Voyages, Botany, and Representations of Nature, David Philip Miller and Peter Hanns Reill (eds), Cambridge University Press, Cambridge: 38-57.

McMinn, Winston G 1970, Allan Cunningham, Botanist and Explorer, Melbourne University Press, Melbourne.

McManus, Charles R 2002, Biodiversity and the Law: Intellectual Property, Biotechnology and Traditional Knowledge, Earthscan, London.

Meek, Ronald L 1976, Social Science and the Ignoble Savage, Cambridge University Press, Cambridge.

Mgbeoji, Ikechi 2006, Global Biopiracy: Patents, Plants and Indigenous Knowledge, University of British Columbia Press, Vancouver.

Powell, Richard C 2007, 'Geographies of science: histories, localities, practices, futures', Progress in Human Geography 31(3): 309-329.

Sharman, GB 1974, 'Observations upon the animals made by the naturalists of the "Endeavour"', Oceania 44(3): 216-232.

Sillitoe, Paul (ed) 2007, Local Science vs Global Science: Approaches to Indigenous Knowledge in International Development, Berghan Books, New York and Oxford.

Smith, Bernard 1960, European Vision and the South Pacific 1768-1850, Oxford University Press, London.

Smith, Keith Vincent 1992, King Bungaree: A Sydney Aborigine meets the Great South Pacific Explorers, 1799-1830, Kangaroo Press, Kenthurst, NSW.

Smith, Vanessa 2010, Intimate Strangers: Friendship, Exchange and Pacific Encounters, Cambridge University Press, Cambridge.

Spivak, Gayatri Chakravorty 1988, 'Can the subaltern speak?', in Marxism and the Interpretation of Culture, Cary Nelson and Lawrence Grossberg (eds), University of Illinois Press, Chicago: 271-313.

Spurr, David 1993, The Rhetoric of Empire: Colonial Discourse in Journalism, Travel Writing, and Imperial Administration, Duke University Press, Durham and London.

Strong, Pauline Turner 1986, 'Fathoming the primitive: Australian Aborigines in four explorers' journals, 1697-1845', Ethnohistory 33(2): 175-194. 
Troy, Jakelin 1996, "“By slow degrees we began to understand each other ... even in this the natives have the advantage"', in Exchanges: Cross-Cultural Encounters in Australia and the Pacific, Ross Gibson (ed), Museum of Sydney and Historic Houses Trust of NSW, Sydney: 22-57.

Turnbull, David 1997, 'Reframing science and other local knowledge traditions', Futures 29(6): 551-562.

- 2002, 'Travelling knowledge: narratives, assemblage and encounters', in Instruments, Travel and Science: Itineraries of Precision from the Seventeenth to the Twentieth Century, Marie-Noelle Bourguet, Christian Licoppe and Otto $\mathrm{H}$ Sibum (eds), Routledge, London: 273-294.

- 2005, 'Locating, negotiating, and crossing boundaries: a Western Desert land claim, the Tordesillas line, and the West Australian border', Environment and Planning D: Society and Space 23: 757-770.

- 2009, 'Boundary-crossings, cultural encounters and knowledge spaces in early Australia', in The Brokered World: Go-Betweens and Global Intelligence, 1770-1820, Simon Schaffer, Lissa Robets, Raj Kapil and James Delbourgo (eds), Watson Publishing International LLC, Sagamore Beach, MA: 387-428.

Turnbull, Paul 2000, 'Introduction: learning to understand western and indigenous sciences', Humanities Research 1: 7-20.

Vallance, Thomas George, DT Moore and EW Groves (compilers) 2001, Nature's Investigator: The Diary of Robert Brown in Australia, 1801-1805, Australian Biological Resources Study, Canberra.

Verran, Helen 2002, 'A postcolonial moment in science studies: alternative firing regimes of environmental scientists and Aboriginal landowners', Social Studies of Science 32: 729-760.

- 2009, 'On assemblage', Journal of Cultural Economy 2(1-2): 169-182.

von Lewinski, Silke and A v Hahn (eds) 2004, Indigenous Heritage and Intellectual Property: Genetic Resources, Traditional Knowledge and Folklore, Kluwer Law International, The Hague and New York. 